Vol. 4, No. 1, 2019

\title{
ANALYSIS OF ECOLOGICAL SAFETY OF EMISSIONS FROM PRODUCTION OF CARBON PRODUCTS
}

\author{
Karina Belokon', Yuriy Belokon', Larysa Klymenko \\ Zaporizhzhia National University, \\ 66, Zhukovsky Str., Zaporizhzhia, 69600, Ukraine, \\ kv.belokon@gmail.com
}

https://doi.org/10.23939/ep2019.01.052

Received: 10.03 .2019

(C) Belokon’ K., Belokon’ Y., Klymenko L., 2019

\begin{abstract}
The risk to the health of the population from carbon oxide and hydrocarbon waste influence of carbon producing enterprises is estimated in this work. After analyzing the ecological safety of emissions of the carbon producing enterprises it was determined that their activity belongs to the average level of risk and ability to get respiratory organs diseases, sight, cardiovascular and central nervous system diseases for old people, pregnant women and children.
\end{abstract}

Key words: gaseous waste, carbon oxide, hydrocarbons, pollution, atmosphere, ecological safety, inhabitants, health risk.

\section{Introduction}

The annual tendency to the increase in harmful emissions from industrial enterprises (by 3-7 \% on average) has been recently observed in Ukraine. The analysis shows that about 10 million tons of harmful chemicals are released into the atmosphere annually; moreover, about $70 \%$ of them belong to the waste of stationary sources. This problem is particularly relevant to regions with a significant concentration of industrial enterprises. This fact underlines the urgency of solving the problem of health protection of the population that lives in the industrially loaded territories of Ukraine [1,2].

The safe level of ensuring air quality is one of the main tasks of state policy, that is confirmed and reflected in the latest state strategic and planning documents, in particular, in the Law of Ukraine "On Sanitary and Epidemiological Welfare of the Population" and in the Strategy of National Environmental Policy of Ukraine in the period up to 2020 (Law of Ukraine $\mathrm{N}^{\mathrm{o}}$ 2818-VI dated December 21, 2010).

At the same time, the methodology for the public health risk assessment in these documents is considered to be the most effective managing tool. It allows us to characterize the probability of harmful influence on the people's health and substantiate the safety of the population, living in the areas located near industrial enterprises, highways or other "risk zones" as a result of actual or potential pollution of the environment, in particular, atmospheric air.

Thus, the purpose of the study is to estimate the public health risk from air pollution produced by the enterprises of carbon products.

The general procedure for the public health risk assessment (Human Health Risk Assessment), developed and recommended by the US Environmental Protection Agency was used in the research. It involves four interrelated steps [3]: hazard identification, exposure assessment, dose-response assessment and risk characteristics.

\section{Experimental part}

Zaporizhzhia region is one of the loaded regions in terms of industrial potential, caused by the concentration of ferrous and nonferrous metallurgy enterprises, heat and power engineering, nuclear energy, chemistry, mechanical engineering [1]. The fact that enterprises the main polluters, are concentrated in several industrial zones located near the residential buildings of the city (about 25 thousand people live within the sanitary protection zones of the main air pollutants of the regional center) is the specific feature of Zaporizhzhia. The situation is aggravated by the location of the main industrial hub on the windward side in relation to the residential city areas, which increases their pollution. So, the air pollution forecast will allow taking into account these data when planning the activity of industrial facilities in Zaporizhzhia.

The most common pollutants in Zaporizhzhia are dust, sulfur compounds, nitrogen oxides, carbon 
monoxide and hydrocarbons which are the main reasons of ecologically dependent diseases and states.

The analysis of environmental safety of pollutants emissions was carried out in the zone of the enterprise Private Joint-Stock Company "Ukrainskyi Hrafit" influence, because its emissions contain $\mathrm{CO}(82 \%)$ and toxic hydrocarbons $(5,5 \%)$, such as benzopyrene, benzene, styrene and phenol.

PrJSC "Ukrainskyi Hrafit" is the leading Ukrainian manufacturer of graphitized electrodes for electric steelmaking, ore-thermal and other types of electric furnaces, carbon, electrode and anode masses for electrodes, carbon paste, carbon-lining materials (blocks) for metallurgical, machine-building, chemical and other industry complexes.

\subsection{Results of the hazard identification stage}

The company PrJSC "Ukrainskyi Hrafit" releases into the atmosphere 27 pollutants of 1-4 hazard classes, which influence public health in different ways [2]. Characteristics of the scenario and the way of pollutants exposure selected for conditions of the enterprise PrJSC "Ukrainskyi Hrafit" are described in Table 1. The main way of pollutants entry into the human body is inhalation of the atmospheric air.

Table 1

\section{Characteristics of scenario and way of pollutants influence selected for the conditions of PrJSC "Ukrainskyi Hrafit" company}

\begin{tabular}{|l|c|}
\hline \multicolumn{1}{|c|}{$\begin{array}{c}\text { Part of the } \\
\text { exposure }\end{array}$} & Exposure characteristic \\
\hline $\begin{array}{l}\text { Negative impact } \\
\text { factor }\end{array}$ & $\begin{array}{c}\text { The company PrJSC "Ukrainskyi } \\
\text { Hrafit" emissions into the atmospheric } \\
\text { air from stationary organized sources }\end{array}$ \\
\hline Influence path & \multicolumn{1}{|c|}{ Inhalation } \\
\hline $\begin{array}{l}\text { Influence } \\
\text { scenario }\end{array}$ & Residential area \\
\hline $\begin{array}{l}\text { Type of contact } \\
\text { (by time) }\end{array}$ & Acute \\
\hline $\begin{array}{l}\text { The age of the } \\
\text { exposed group }\end{array}$ & The average person (30 years) \\
\hline
\end{tabular}

The selection of priority pollutants which PrJSC "Ukrainskyi Hrafit" emissions contain was made taking into account the amount of waste volume in the atmospheric air and the results of their ranging according to comparative indexes of carcinogenic and non-carcinogenic danger. As a result, a list of priority pollutants was made.

The list includes 12 chemical compounds, where benzopyrene belongs to class 1 of hazards (extremely hazardous substances); nitrogen dioxide, benzene, manganese and its compounds, hydrogen sulfide, sulfur dioxide, styrene and phenol belong to class 2 of hazards (highly hazardous substances); acenaphthene and suspended substances belong to hazards class 3, naphthalene and carbon monoxide belong to hazards class 4.

As part of the priority pollutants, 3 chemicals have a carcinogenic effect. According to the classification of the International Agency for the Study of Cancer, benzene belongs to the group of class 1 of carcinogens, that is, the most dangerous for humans; benzopyrene and styrene - to the group of possible human carcinogens.

\subsection{The results of the exposure assessment stage}

The research area of public health risks from the emissions of stationary sources of PrJSC "Ukrainskyi Hrafit" (area $7 \times 7 \mathrm{~km}$ ) was divided by a receptor grid into 8 identical segments of $45^{\circ}$ by rumba wind direction, starting from the north $\left(0^{\circ}\right)$. Each segment "was cut" from the center of the enterprise, defined behind the borders of three industrial sites, into sectors from 500 to $3500 \mathrm{~m}$ with a grid step of $500 \mathrm{~m}$.

Average concentrations of pollutants, the calculation of which was carried out at 56 nodes at a given receptor grid, not taking into account city's background, were offered by PrJSC "Ukrainskyi Hrafit".

When determining the exposed population, its density at the receptor nodes and the geography of the pollution sources location were taken into account.

High population density near the industrial site of PrJSC "Ukrainskyi Hrafit" is observed at a distance of $3000 \mathrm{~m}$ in the north-east direction (15-19 thousand people per $1 \mathrm{~km}^{2}$ ) and at a distance of $2500 \mathrm{~m}$ in the south-west direction (11-15 thousand people per $1 \mathrm{~km}^{2}$ ). The public health risk assessment was carried out at 14 nodes of a given receptor grid in the northeast and southwest wind directions.

\subsection{The results of the evaluation phase of the "dose-response"}

The obtained data levels of averaged concentrations were compared with reference concentrations data to estimate the probable emission influence on the health of the exposed population with the acute inhalation effect from the main pollutants of PrJSC "Ukrainskyi Hrafit. It allowed us to estimate the risk for public health consequently. The reference concentrations excess at 56 nodes of the receptor grid is characteristic of manganese and its compounds, benzopyrene, naphthalene and benzene. 


\subsection{The stage results of public health risk characteristics}

The air pollution risk characteristics from stationary sources of PrJSC "Ukrainskyi Hrafit" in the calculated nodes of the receptor grid were determined. They include [2]:

- calculations of individual and total cancer risks to the health of the exposed population;

- calculations of non-carcinogenic risks in the form of hazard coefficients and hazard indexes for separate substances;

- calculations of the individual death risk from emissions of dust with particle diameter less than 10 microns.

Among the main pollutants presented in the residential area, benzopyrene, benzene and styrene are carcinogenic. The results of calculations of an individual cancer risk to public health in the nodes of the receptor grid indicate a low level of risk (level De minimas) $\left(I C R=10^{-9} \div 10^{-6}\right)$ at acute exposure for all three substances. Such risks do not require any additional measures decrease waste and their levels may be subjected to periodic monitoring only.

The total cancer risk in 14 nodes of the receptor grid in the northeast $\left(\mathrm{R}_{\text {sum }}=2.25 \cdot 10^{-5}\right)$ and southwest $\left(\mathrm{R}_{\text {sum }}=1.87 \cdot 10^{-5}\right)$ directions indicates acceptable level of cancer risk $\left(10^{-6}<\mathrm{R}_{\text {sum }}<10^{-4}\right)$ at acute exposure. These levels of risk are subjected to constant monitoring.

It was calculated that benzene and benzapyrene are the most dangerous in terms of the total cancer risk in receptor grid nodes during acute exposure.

The results of hazard coefficients calculations in assessing the acute inhalation effects of pollutants emissions from PrJSC "Ukrainskyi Hrafit" indicate the excess of safe levels (HQ > 1) in the calculated nodes of the receptor grid for the following substances:

a) in the northeast direction for:

- manganese and its compounds at a distance of $500 \mathrm{~m}(\mathrm{HQ}=1,036)$, but this is not in the residential area, therefore, the health risk is absent;

- benzopyrene at a distance of 2500 to $3500 \mathrm{~m}$ $(\mathrm{HQ}=1,12 \div 1,23)$;

- phenol at a distance of 2500 to $3500 \mathrm{~m}$ $(\mathrm{HQ}=1,0683 \div 1,2517)$;

b) in the south-west direction for:

- benzopyrene at a distance of 2500 to $3500 \mathrm{~m}$ $(\mathrm{HQ}=1,02 \div 1,26)$;

- phenol at a distance of $3000 \mathrm{~m}(\mathrm{HQ}=1,12)$.

The results of hazard indexes calculations indicate the excess of safe levels of exposure (HI> 1) of the main combined pollutants during the inhalation exposure. They are shown in Table 2.

Table 2

Hazard Index Calculation Results

\begin{tabular}{|l|c|c|c|}
\hline \multicolumn{1}{|c|}{$\begin{array}{c}\text { Organs / } \\
\text { Systems }\end{array}$} & Distance, $\mathrm{M}$ & $\begin{array}{c}\text { North-east } \\
\text { hazard } \\
\text { indexes }\end{array}$ & $\begin{array}{c}\text { South-west } \\
\text { hazard } \\
\text { indexes }\end{array}$ \\
\hline $\begin{array}{l}\text { Respiratory } \\
\text { system }\end{array}$ & $500-3000$ & $\begin{array}{c}1.477- \\
2.7808\end{array}$ & $\begin{array}{c}1.0627- \\
2.0721\end{array}$ \\
\hline $\begin{array}{l}\text { Organs of } \\
\text { vision }\end{array}$ & $2500-3500$ & $1.063-1.31$ & 1.12 \\
\hline $\begin{array}{l}\text { Parenchymal } \\
\text { organs }\end{array}$ & $2500-3500$ & $1.08-1.32$ & 1.13 \\
\hline $\begin{array}{l}\text { Cardiovascular } \\
\text { system }\end{array}$ & $2500-3500$ & $1.13-1.36$ & 1.17 \\
\hline $\begin{array}{l}\text { Central nervous } \\
\text { system }\end{array}$ & $2500-3500$ & $1.23-1.44$ & $0.79-1.27$ \\
\hline Immune system & $2500-3500$ & $1.08-1.23$ & $1,02-1,26$ \\
\hline $\begin{array}{l}\text { Developmental } \\
\text { birth defects }\end{array}$ & $2500-3500$ & $1.142-$ & $1.1-1.32$ \\
\hline
\end{tabular}

Hazard indexes at points of high population density (at a distance of $3000 \mathrm{~m}$ in the north-east direction and $3000 \mathrm{~m}$ in the south-west direction) are shown in Fig. 1, 2.

The values of hazard indexes for acute inhalation exposure are at an average level. As a result of it there is a risk of adverse effects in particularly sensitive subgroups of the population (elderly, pregnant and children) $[4,5]$.

The most actual in forming hazard indexes are phenol $(63,93 \%)$ and sulfur dioxide $(19,9 \%)$ for respiratory system; phenol $-98,54 \%$ for parenchymal organs, $96 \%$ for cardiovascular system,58,36 \% for central nervous system; benzopyrene $-95,74 \%$ for congenital defects of development.

The formation of hazard index from PrJSC "Ukrainskyi Hrafit" emissions for the people's immune system completely depends on benzopyrene and for the organs of sight - on phenol.

Monitoring and epidemiological studies conducted in many countries prove that numerous health dangerous effects, including diseases and death from respiratory and cardiovascular pathologies are caused mainly by air pollution from substances in the form of suspended solid particles $\left(\mathrm{PM}_{10}\right)$.

Calculations show that additional deaths are 0.07 per 1000 population during life that corresponds to about two additional deaths at the nodes of the receptor grid. 


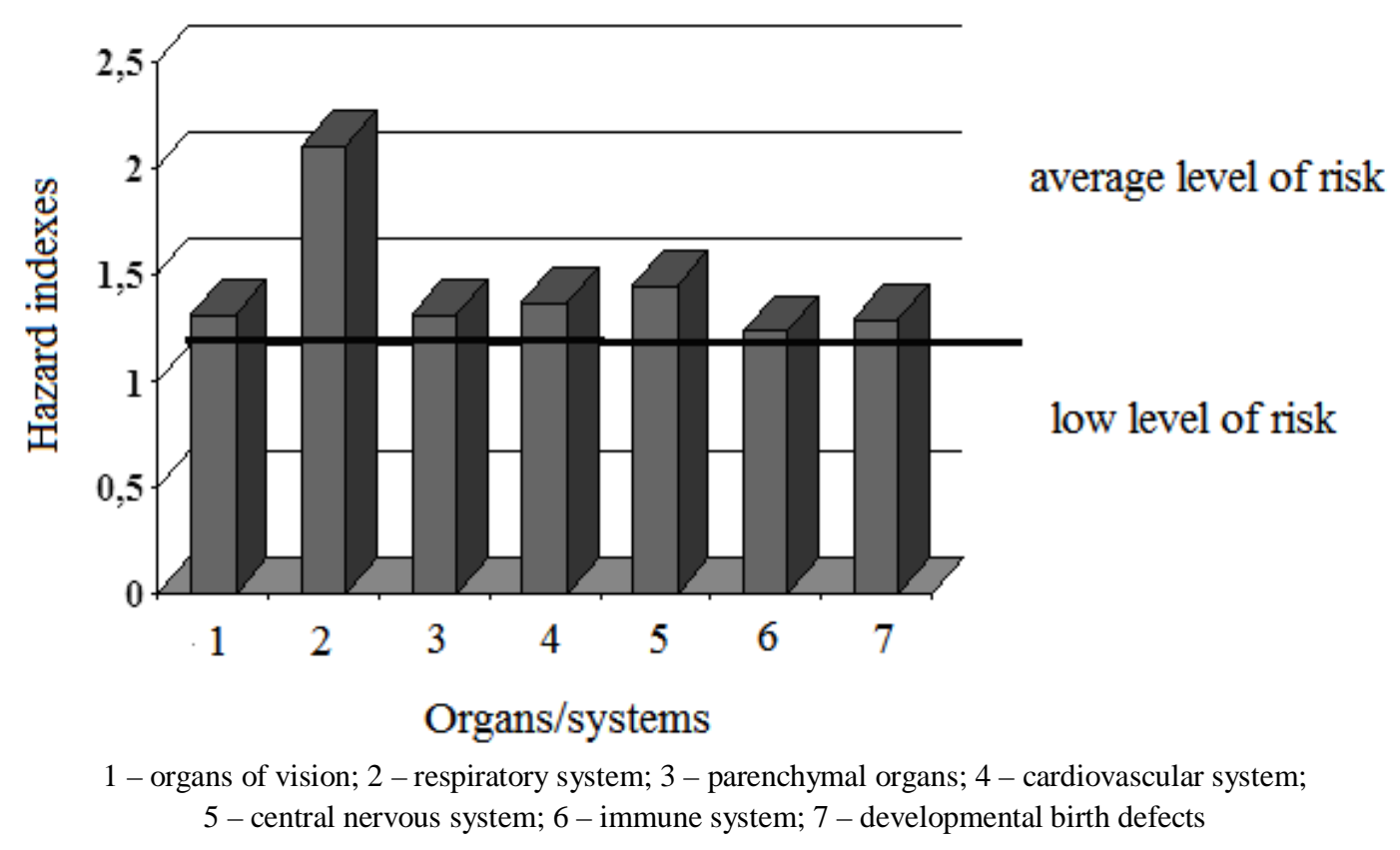

Fig. 1. Hazard indexes (HI) for public health at a point of high population density at a distance of $3000 \mathrm{~m}$ in the north-east direction from the center of the industrial site of PrJSC "Ukrainskyi Hrafit»

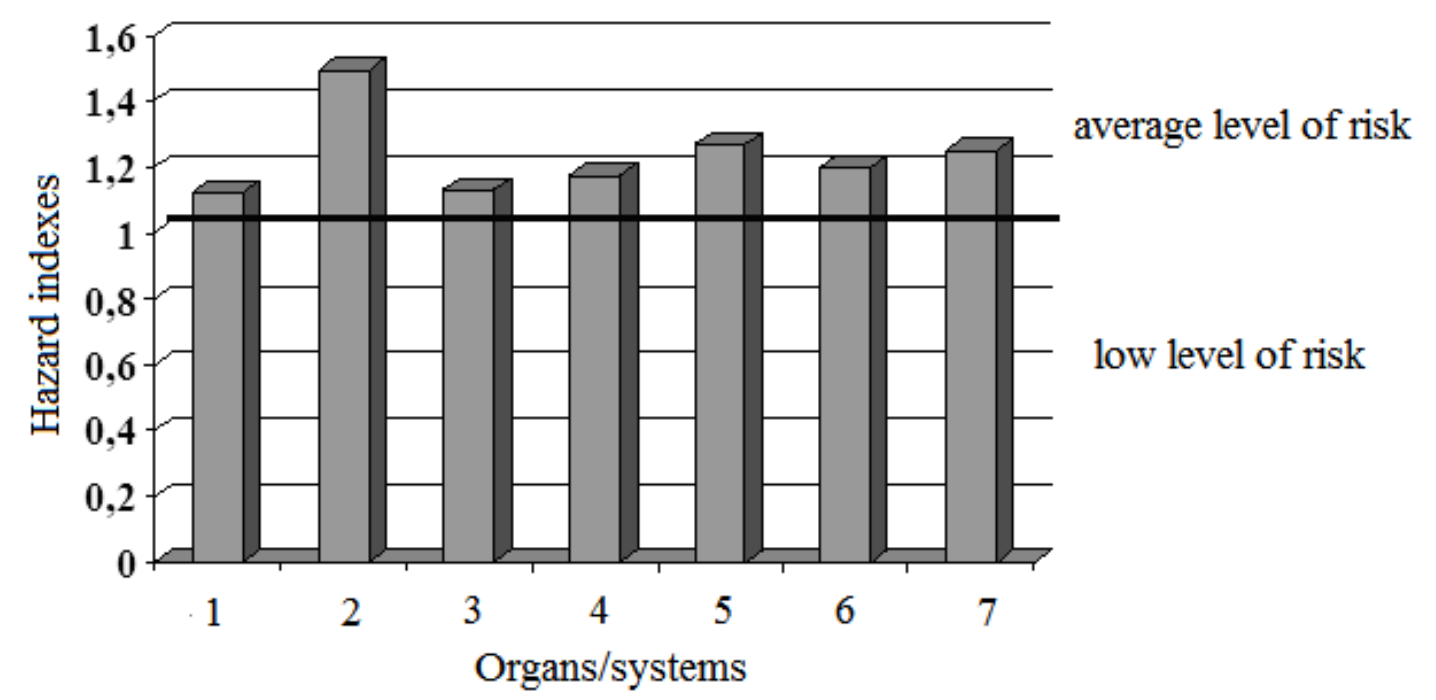

1 - organs of vision; 2 - respiratory system; 3 - parenchymal organs; 4 - cardiovascular system; 5 - central nervous system; 6 -immune system; 7 - developmental birth defects

Fig. 2. Hazard indexes (HI) for public health at a point of high population density at a distance of $3000 \mathrm{~m}$ in the south-west direction from the center of the industrial site of PrJSC "Ukrainskyi Hrafit»

\section{Results and discussion}

The results of carbon manufacturing enterprise analysis for environmental safety show that benzene, benzopyrene, phenol and styrene are harmful substances that directly affect human health. The influence of these components reveals signs of the respiratory, vision and parenchymal organs diseases, indicates the problems with cardiovascular, central nervous and immune systems, as well as developmental birth defects particularly for sensitive subgroups of the population (elderly, pregnant and children).

\section{Conclusions}

The analysis of environmental safety of emissions from the carbon manufacturing enterprise shows:

- total carcinogenic risk in 14 nodes of the receptor grid in the north-east $\left(\mathrm{R}_{\text {sum }}=2,25 \cdot 10^{-5}\right)$ and south-west $\left(\mathrm{R}_{\text {sum }}=1,87 \cdot 10^{-5}\right)$ directions indicates a low level of 
cancer risk $\left(10^{-6}<\mathrm{R}_{\text {sum }}<10^{-4}\right)$ with acute exposure, which, according to international criteria, is assessed as an acceptable level at which hygienic standards are set for the population;

- the results of calculations of hazard coefficients $(\mathrm{HQ}=1,036 \div 1,2517)$ and hazard indexes $(\mathrm{HI}=1,0627 \div 1,32)$ in estimation of acute inhalation effects of pollutants emissions from production of carbon products are at the average level. This level of risk does not require emergency measures, but cannot be considered as acceptable for human health.

\section{References}

[1] Belokon' K. V. (2011), "About increasing environmental safety of gas emissions metallurgical enterprises", Zbirnyk naukovykh prac "Metalurhiya", vol. 25, pp. 164-169.
[2] Belokon' K. V. (2012), "The analysis of ecological safety of carbon oxide and hydrocarbons waste of the industrial plant of open society "YkrHrafit", Zbirnyk naukovykh prac "Problemy okhorony navkolyshn-oho pryrodnoho seredovyshcha ta ekolohichnoyi bezpeky", vol. 34, pp. 61-71.

[3] Metodychni rekomendatsiyi (2007), Otsinka ryzyku dlya zdorovya naselennya vid zabrudnennya atmosfernoho povitrya, Ukraine, Kiev.

[4] Belokon' K. V. (2015), "The increasing of enterprises of electrode production ecological safety by catalytic neutralization of gas emissions", Vestnik Khar'kovskogo natsional'nogo avtomobil'no-dorozhnogo universiteta, vol. 70, pp. 42-49.

[5] Belokon K. V.: Scientific Bulletin of National Mining University, Scientific and Technical Journal, 2016, 3, 87. (in English) 